\title{
POSLOVNI UDJEL(I) I BRAČNA STEČEVINA KROZ PRAKSU TRGOVAČKIH SUDOVA
}

Tina Jakupak, mag. iur., univ. spec. oec.

\author{
UDK 347.626:347.724(497.5) \\ https://doi.org/10.30925/zpfsr.42.2.17 \\ Ur.: 12. travnja 2021. \\ Pr.: 7. lipnja 2021. \\ Stručni rad
}

\begin{abstract}
Sažetak
Autorica se u svom svakodnevnom radu susreće s parničnim i izvanparničnim predmetima u kojima je predmet spora bračna stečevina na poslovnom udjelu društva s ograničenom odgovornošću. Stoga će se u radu obraditi u prvom dijelu pojmovi i instituti bračne stečevine i poslovnog udjela, u drugom pravna sredstva, tužbe i prijedlozi za određivanje privremene mjere radi utvrđivanja bračne stečevine na poslovnom udjelu te povezati sa sudskom praksom. Pokušat će se odgovoriti na pitanje učinaka prethodnoga jednostranog raspolaganja pravima čiji je upisani imatelj poslovnog udjela (samo) jedan bračni drug. Pritom će se analizirati sukob pravila obiteljskog i trgovačkog prava, a osobit je naglasak dan na sudskim odlukama trgovačkih sudova u Republici Hrvatskoj i Vrhovnog suda Republike Hrvatske. Zaključno, autorica iznosi svoje stajalište o imovinskoj zajednici koju bračni drugovi uspostavljaju kao ovlaštenici na poslovnom udjelu trgovačkog društva.
\end{abstract}

Ključne riječi: poslovni udjel; bračna stečevina; trgovački sud; sudska praksa.

\section{UVOD}

U posljednjih deset, petnaest godina u predmetima trgovačkih sudova sve je više sporova povezanih s poslovnim udjelom i njegovim stjecanjem u sklopu instituta bračne stečevine. ${ }^{1} \mathrm{U}$ istom su razdoblju više puta mijenjani i Obiteljski zakon ${ }^{2}$ i Zakon o trgovačkim društvima. ${ }^{3}$ ZTD je stupio na snagu 1. siječnja 1995. i od tada imovina bračnih drugova mogu biti i poslovni udjel(i) u trgovačkom društvu. Trgovačka društva koja su osnovana prije 1. siječnja 1995., ako su usklađena s odredbama ZTD-a, mogu

* Tina Jakupak, mag. iur., univ. spec. oec., sutkinja Trgovačkog suda u Zagrebu; tina.jakupak@, tszg.pravosudje.hr. ORCID: https://orcid.org/0000-0003-3645-2474.

1 Točan broj predmeta radi utvrđenja bračne stečevine na poslovnom udjelu zaprimljenih na trgovačke sudove ne može se utvrditi budući da se nedosljedno vode podatci o tome. Predmeti se vode kao status-ostalo što obuhvaća niz predmeta iz područja prava društava.

2 Obiteljski zakon, Narodne novine, br. 103/15., 98/19., 47/20. (dalje: Obz).

3 Zakon o trgovačkim društvima, Narodne novine, br. 111/93., 34/99., 121/99., 52/00., 118/03., 107/07., 146/08., 137/09., 152/11. 111/12., 125/11., 68/13., 110/15., 40/19. (dalje: ZTD). 
biti predmet bračne stečevine odnosno točnije poslovni udjeli u tim društvima. U odnosu na tu imovinu, za poslovne udjele, Obz ne propisuje neka posebna pravila. Ako se usporedi ZTD uočava se da niti taj zakon ne obuhvaća posebna pravila za imovinu bračnih drugova na poslovnom udjelu. Poslovni udjel u društvu s ograničenom odgovornošću predmet je bračne stečevine ako je temeljni kapital koji se unosi u društvo bio stečen radom ili potječe od rada tijekom trajanja bračne zajednice. ZTD kao bitnu pretpostavku za stjecanje članstva u društvu predviđa upis u knjigu poslovnih udjela odnosno upis u sudski registar trgovačkog suda. Pravo društava ne poznaje opciju ipso iure stjecanja poslovnog udjela na temelju bračne stečevine pa zbog toga dolazi do sukoba s obiteljskim pravom. Prema pravu društava jedini ovlašteni za ostvarivanje članskih prava koja proizlaze iz poslovnog udjela je formalno upisani bračni drug. S tim u vezi u praksi se pojavljuje izazov kako primijeniti normu Obz-a da su bračni drugovi suvlasnici svega što ulazi u predmet bračne stečevine na jednake dijelove, pa tako i poslovnog udjela u društvu.

$\mathrm{U}$ nedostatku pravnih pravila $\mathrm{u}$ oba spomenuta zakona povezanih s bračnom stečevinom na poslovnom udjelu, dolazi do sukoba pravila obiteljskog prava i prava društava te pravne praznine koju pokušava protumačiti sudska praksa i odgovoriti na niz pitanja: kojem zakonu dati prednost, koje se pretpostavke trebaju ispuniti za stjecanje poslovnog udjela jednoga bračnog druga na poslovnom udjelu kojeg je drugi bračni drug stekao za vrijeme trajanja braka odnosno bračne zajednice, kako provesti upis - što je temelj upisa, kao i druga brojna pitanja.

Kada je riječ o poslovnom udjelu kao predmetu bračne stečevine misli se ponajprije na poslovni udjel(e) u društvima kapitala: društvu ograničenom odgovornošću i jednostavnom društvu s ograničenom odgovornošću. Ako je riječ o bračnoj zajednici odnosno braku, ${ }^{4}$ govori se i o izvanbračnoj zajednici budući da je izjednačena s bračnom zajednicom. ${ }^{5}$

U ovome je radu naglasak stavljen na pravno uređenje imovinskih odnosa bračnih drugova u hrvatskom pravu u odnosu na poslovni udjel u trgovačkom društvu s ograničenom odgovornošću. Cilj je rada prikazati institute obiteljskog prava i prava društava, prikazati i analizirati pravne odredbe kojima se uređuju imovinski odnosi bračnih drugova u hrvatskom pravu u odnosu na poslovni udjel. Uvidom u sudsku praksu i analizom presuda, autorica će upozoriti na mehanizme pravne zaštite bračnoga druga koji nije upisan u knjigu poslovnih udjela trgovačkog društva kao član i imatelj poslovnog udjela, odnosno u sudskom registru nadležnog suda.

\section{BRAČNA STEČEVINA I POSLOVNI UDJEL}

Pojam bračne stečevine novijeg je datuma. Naime, tijekom važenja Zakona o braku i porodičnim odnosima ${ }^{6}$ pojam bračne stečevine nije postojao. U hrvatskom

\footnotetext{
4 Čl. 12. Obz.

5 Čl. 11. Obz.

6 Zakon o braku i porodičnim odnosima, Narodne novine, br. 11/78., 27/78., 45/89., 51/89., 59/90., 25/94., 162/98. (dalje: ZBPO).
} 
se pravu javlja u Obiteljskom zakonu iz 1998. ${ }^{7}$ Bračna je stečevina imovina koju su bračni drugovi stekli radom tijekom trajanja bračne zajednice ili potječe iz te imovine. ${ }^{8}$ Prema ZBPO-u postojao je institut zajedničke imovine koja se dijelila prema doprinosu pojedinoga bračnog druga njezinom stvaranju. Za razliku od zajedničke imovine, bračna se stečevina dijeli između bračnih drugova na jednake dijelove.

Brak i bračna zajednica različiti su pojmovi. Pritom valja istaknuti da bračna zajednica može trajati isključivo tijekom trajanja braka, a za bračnu je zajednicu bitno postojanje volje bračnih drugova radi ostvarivanja i dijeljenja života, čak i ako žive odvojeno. ${ }^{9}$ Moguća je i suprotna situacija: bračni drugovi žive na istoj adresi, ali više ne ostvaruju i ne dijele život i sadržaj zajedničkoga života. Za određenje bračne stečevine bitno je trajanje bračne zajednice. Sklapanjem braka ne mora nastati istodobno i bračna zajednica. Nije dostatno da brak formalno postoji, već je potrebno da bračni drugovi stvarno žive u bračnoj zajednici. S druge strane, bračna je zajednica sastavni dio braka i može trajati jedino i isključivo tijekom braka. Sud treba utvrditi bračnu zajednicu ako postane sporno smatra li se određena imovina bračnom stečevinom ili je riječ o vlastitoj imovini. Teret dokazivanja o trenutku prestanka bračne zajednice na onom je bračnom drugu koji tvrdi da je bračna zajednica određenog dana prestala jer se u protivnom presumira da bračna zajednica traje sve do prestanka braka. U sudskoj je praksi ocijenjeno da okolnost što su stranke stanovale odvojeno, uz činjenicu da je do toga došlo voljom stranaka i da su se dugotrajno nastavili svakodnevni kontakti stranaka, ne upućuje na prekid bračne zajednice. ${ }^{10}$

Bračni su drugovi suvlasnici bračne stečevine u jednakim dijelovima, ako nisu drukčije ugovorili. ${ }^{11}$ Riječ je o neoborivoj zakonskoj presumpciji, te se u sudskom postupku pokrenutom radi utvrđenja bračne stečevine više ne utvrđuju doprinosi bračnih drugova u stjecanju bračne stečevine, ako je riječ o imovini stečenoj nakon 30. lipnja $1999 .{ }^{12}$

Na bračnu se stečevinu primjenjuju odredbe propisa kojima se uređuju stvarno pravni i obvezno pravni odnosi, ako Obz-om nije drukčije određeno. ${ }^{13}$ Bračna je stečevina ukupnost stvari i prava, te s obzirom na to da je u suvlasništvu, njome bračni

7 Obiteljski zakon, Narodne novine, br. 162/98., 116/03., na snazi: od 30. prosinca 1998. do 21. srpnja 2003., u primjeni od 1. srpnja 1999.

8 Čl. 252. Obz iz 1998.; čl. 36. st. 1. Obz iz 2015.; više o pravnoj naravi bračne stečevine Aleksandra Korać Graovac, „Imovinski odnosi“, u: Obiteljsko pravo, Mira Alinčić et al., 3. izmijenjeno i dopunjeno izd. (Zagreb: Narodne novine, 2007.), 501 i 505; Mladen Sučević, „Nekretnine kao predmet bračne stečevine“, u: Nekretnine kao objekti imovinskih prava, Bienenfeld, Josip et al. (Zagreb: Narodne novine, 2006.), 45.

9 Visoki trgovački sud Republike Hrvatske Pž 80/2017 od 18. prosinca 2019.

10 Vrhovni sud Republike Hrvatske Rev 361/92, od 12. ožujka 1992.

11 Čl. 36. st. 3. Obz.

12 Dan prestanka važenja Zakona o braku i porodičnim odnosima koji je institut bračne stečevine regulirao na način da je bilo moguće utvrđivati različite doprinose bračnih drugova u stjecanju bračne stečevine.

13 Čl. 38. Obz. 
drugovi upravljaju po općim pravilima o upravljanju suvlasničkom stvari. ${ }^{14,15}$

Ono što je bitno za naglasiti je činjenica da je u odnosu na ocjenu prava vlasništva bračnih drugova na bračnoj stečevini mjerodavno pravo koje je bilo na snazi u vrijeme stjecanja imovine. ${ }^{16}$ Tako se u odnosu na imovinu stečenu prije 1. srpnja 1999. primjenjuju propisi ZBPO-a i institut zajedničke imovine, dok se u odnosu na imovinu stečenu nakon navedenoga datuma primjenjuje Obz i institut bračne stečevine. Ako je imovina tijekom bračne zajednice stečena u oba pravna režima, tada je zadatak suda prvo utvrditi točno kada je imovina stečena, kao i ostale pretpostavke. Na tako utvrđeno činjenično stanje potrebno je primijeniti materijalno pravo, ili institut zajedničke imovine, ili institut bračne stečevine, te s tim u vezi provesti dokaze koje su predložile stranke.

Obz kao pretpostavku za utvrđenje bračne stečevine ne predviđa da brak između stranaka mora biti razveden. Prestanak braka, dakle nije uvjet za utvrđenje da je jedna od stranaka suvlasnik na zajedničkoj imovini bračnih drugova stečenoj zajedničkim radom tijekom braka. ${ }^{17}$

Bračna stečevina ujedno će biti i imovina koja potječe iz imovine koja predstavlja bračnu stečevinu, neovisno o trenutku derivativnoga stjecanja nove imovine. ${ }^{18}$ To je zbog toga što jednom kada neka stvar ili pravo uđe u sastav bračne stečevine (radom tijekom trajanja bračne zajednice), ista ta stvar ili pravo mogu kasnije poslužiti za stjecanje neke druge stvari ili prava. Iz toga proizlazi zaključak, za koji je suglasna teorija obiteljskog prava i sudska praksa, prema kojem će sve što potječe od stvari ili prava koja su bila predmet bračne stečevine, također biti dijelom bračne stečevine, neovisno o tome je li do derivativnoga stjecanja novih stvari ili prava došlo tijekom ili nakon prestanka bračne zajednice. ${ }^{19}$

Poslovni je udjel osnovni pojam kojim se određuju odnosi članova u društvu s ograničenom odgovornošću. ${ }^{20}$ Članstvo u društvu stječe se i određuje poslovnim udjelom. ${ }^{21}$ Ulog u društvo je ono što se mora unijeti u društvo i iskazuje se u iznosu njegova temeljnog kapitala, da bi se ispunila članska obveza prema društvu za stjecanje

14 Zakon o vlasništvu i drugim stvarnim pravima, Narodne novine, br. 91/96., 68/98., 137/99., 22/00., 73/00., 114/01., 79/06., 141/06., 146/08., 38/09., 153/09., 90/10., 143/12., 94/17., 152/14., 81/15. (dalje: ZV).

15 Vlado Belaj, „Bračna stečevina po Obiteljskom zakonu“, Zbornik Pravnog fakulteta Sveučilišta u Rijeci 23, br. 1 (2002): 185.

16 Vrhovni sud Republike Hrvatske Rev 291/05 od 30. svibnja 2006.; Vrhovni sud Republike Hrvatske Rev 1331/08 od 17. prosinca 2009.; Visoki trgovački sud Republike Hrvatske Pž5014/2016 od 29. ožujka 2017.

17 Županijski sud u Varaždinu Gž 1064/07-2 od 13. veljače 2008.

18 Vrhovni sud Republike Hrvatske Rev 393/2011-3 od 5. ožujka 2014.

19 Ivan Šimović, „Poslovni udjeli u društvu s ograničenom odgovornošću kao predmet bračne stečevine u Republici Hrvatskoj - teorijske dvojbe i izazovi u praksi“", u: Zbornik radova Šesti međunarodni naučni skup Dani porodičnog prava "Imovinskopravni aspekti porodičnih odnosa” (Mostar: Pravni fakultet Univerziteta u Mostaru, 2018.), 255-265.

20 Više o poslovnom udjelu kao ukupnosti prava i obveza člana društva vidi Jakša Barbić, Pravo društava. Knjiga 2. Društva kapitala. Sv. 2. (Zagreb: Organizator, 2020.), 90; Zvonimir Slakoper, u: Komentar Zakona o trgovačkim društvima, Gorenc et al. (Zagreb: RRiF-plus, 2004.), 571.

21 Barbić, Pravo društava. Knjiga 2. Svezak 2, 91. 
članstva, a članstvom se određuje pravni položaj člana u društvu. ${ }^{22} \mathrm{Ne}$ postoji pravo vlasništva trgovačkih društava u stvarno pravnom smislu. Stoga ni fizičke ni pravne osobe ne mogu biti nositeljem prava suvlasništva ili samovlasništva određenog trgovačkog subjekta u stvarno pravnom smislu. To može imputirati razumijevanje pojma imovine u kontekstu većine drugih predmeta bračne stečevine, posebice vlasništva nad stvarima. ${ }^{23}$

Poslovni udjel nastaje upisom u sudskim registar, a prestaje brisanjem društva iz sudskog registra ili povlačenjem poslovnog udjela. Pritom članovi društva mogu imati više poslovnih udjela u istom društvu. ${ }^{24} \mathrm{Ti}$ su poslovni udjeli međusobno samostalni. Glavna je značajka društva s ograničenom odgovornošću u Republici Hrvatskoj da se njegovi poslovni udjeli ne mogu izraziti u vrijednosnim papirima, pa se sukladno tomu ne mogu ni uvrstiti na uređeno tržište..$^{25}$ Podredno je nužno uzeti u obzir da udjeli u društvima s ograničenom odgovornošću niti nisu prema zakonu vrijednosni papiri ${ }^{26}$ te da ed ipso nisu usmjereni da se njima trguje na tržištu. ${ }^{27}$

U predmetima (presudama) koji će se analizirati u ovom radu, najčešće je predmet tužbenoga zahtjeva utvrđivanje bračne stečevine na poslovnom udjelu, u tzv. obiteljskim društvima, društvima u kojima su članovi bračni drugovi i/ili najčešće jedan bračni drug je upisan kao član društva, a ostali članovi obitelji (uže ili šire) su zaposlenici i/ili žive upravo od rada i poslovanja tog društva. Čest je slučaj da je upisani član društva ujedno i član uprave. Riječ je o obiteljskim, zatvorenim društvima. Dobit društva prihod je te obitelji. ${ }^{28}$

Bračnu stečevinu trebala bi činiti sva subjektivna imovinska prava koja proizlaze iz imovinskopravnih odnosa bračnih drugova pod daljnjim uvjetima postojanja rada $\mathrm{i}$ bračne zajednice tijekom njihovog stjecanja. Uzimajući u obzir relativnost obveznog prava, u bračnu stečevinu ne bi ulazila sva imovina, nego samo ona koja se odnosi na subjektivna stvarna prava, za razliku od subjektivnih obveznih prava na tražbine, koja izvorno pripadaju isključivo onom bračnom drugu koji je sudionik određenog obveznog odnosa. ${ }^{29}$ Vezano za prava na temelju dionica i poslovnih udjela treba imati

22 Barbić, Pravo društava. Knjiga 2. Svezak 2, 92.

23 Zvonimir Jelinić, „Bračna stečevina u kontekstu Zakona o trgovačkim društvima“, u: Zbornik radova sa znanstvenog skupa: Imovinskopravni aspekti razvoda braka - hrvatski, europski $i$ međunarodni kontekst, ur. Branka Rešetar i Mirela Župan (Osijek: Sveučilište J. J. Strossmayera u Osijeku, Pravni fakultet, 2011.).

24 Čl. 385. ZTD.

25 Edita Čulinović-Herc, Sonja Marinac Rumora i Mihaela Braut Filipović, „Pravno uređenje odnosa članova u zatvorenim (closely held) društvima na primjeru hrvatskog društva $\mathrm{s}$ ograničenom odgovornošću“, Zbornik Pravnog fakulteta Sveučilišta u Rijeci 39, br. 1 (2018), 51.

26 Čl. 385. st. 1. ZTD.

27 Čulinović-Herc, Rumora i Filipović, Pravno uređenje odnosa članova u zatvorenim (closely held) društvima na primjeru hrvatskog društva s ograničenom odgovornošću, 49.

28 Kao jedna od glavnih značajki zatvorenih društava ističe se i mali broj članova. Članovi su tih društava osobno povezani na obiteljskoj ili prijateljskoj osnovi. Među njima (barem na početku odnosa) vlada visoki stupanj povjerenja. Vidi Čulinović-Herc, Rumora i Filipović, Pravno uređenje odnosa članova u zatvorenim (closely held) društvima na primjeru hrvatskog društva s ograničenom odgovornošću.

29 Branka Rešetar i Una Josipović, „Sporna pitanja bračne stečevine s osvrtom na bankovne 
na umu da nije riječ o pravima stvarno pravnoga karaktera, već o specifičnim obvezno pravnim odnosima koji se formiraju ulaganjem novca i stvari te stjecanjem dionica i udjela u društvima. ${ }^{30}$ Prema stajalištu sudova tužba radi utvrđenja bračne stečevine u odnosu na trgovačko društvo ne može se smatrati vlasničkom tužbom, budući da stjecanje prava na poslovne udjele ne može biti temeljeno na stvarnom pravu već isključivo na ZTD-u, odnosno, na općim pravilima obveznog prava. ${ }^{31}$

Predmet bračne stečevine može biti poslovni udjel u društvu s ograničenom odgovornošću uz uvjet da je temeljni kapital uplaćen u novcu, a koji je uplaćen kao ulog, ili da su stvari ili prava koja su unesena kao ulog od jednog od bračnog druga, u trenutku osnivanja društva predstavljali bračnu stečevinu. Postoje i slučajevi kada jedan bračni drug stekne poslovni udjel na temelju ugovora o prodaji i prijenosu poslovnog udjela kao naplatnoga pravnog posla. Tada je uvjet da se kupoprodajna cijena podmiri iz sredstava bračne stečevine da bi tako stečen poslovni udjel predstavljao bračnu stečevinu.

Stranke u sudskim postupcima često zaboravljaju da je poslovni udjel imovinsko pravo. Međutim, to ne znači da članu društva koji ima taj poslovni udjel pripadaju imovinska prava nad imovinom koja je imovina društva. ${ }^{32}$

U praksi je jedan bračni drug član društva odnosno kupac, odnosno stjecatelj poslovnog udjela. Prema pravilima prava društava drugi bračni drug ne može izvan ugovora o prijenosu poslovnog udjela biti stranka toga dvostrano obveznog odnosa prijenosa i kupoprodaje, odnosno darovanja niti ima pravo na tražbinu poput zahtjeva za upisom u knjigu poslovnih udjela i sudski registar, iako stječe pravo (suovlaštenik) na predmetnom poslovnom udjelu na temelju zakonske odredbe o bračnoj stečevini. Dakle, drugi bračni drug nema pravo na tražbinu prema prenositelju i prodavatelju, ali ima pravo na tražbinu prema bračnom drugu stjecatelju odnosno kupcu, pod uvjetom da je poslovni udjel plaćen sredstvima stečenima temeljem rada i za trajanja bračne zajednice. Iz navedenog se zaključuje da poslovni udjel u odnosu na bračne drugove je stečen na temelju dvije pravne osnove: ugovora o prijenosu poslovnog udjela (kupoprodajnog ugovora odnosno ugovora o darovanju) u odnosu na onoga bračnog druga koji je stjecatelj odnosno kupac, a na temelju zakona (Obz) u odnosu na drugoga bračnog druga. ${ }^{33}$

Pojam ovlaštenika na poslovnom udjelu, kao što su bračni drugovi na određenom poslovnom udjelu u određenom društvu, proizlazi iz odredbi citiranih zakona. ${ }^{34}$ Ako je jedan bračni drug nositelj poslovnog udjela u određenom trgovačkom društvu, a koje je osnovano tijekom braka, drugi bračni drug je ovlaštenik na tom poslovnom

ugovore bračnih drugova“, Zbornik radova Pravnog fakulteta u Splitu 50, br. 1 (2013): 117.

30 Jelinić, Bračna stečevina u kontekstu Zakona o trgovačkim društvima, 127.

31 Županijski sud u Varaždinu Gž 958/03-2 od 18. kolovoza 2003.

32 Barbić, Pravo društava. Knjiga 2. Svezak 2, 106.

33 Stvarno pravo govori o prijelazu dijela prava vlasništva stvari koju je stekao jedan bračni drug kao neposredan stjecatelj, na drugoga bračnog druga (ako je riječ o stjecanju radom u bračnoj zajednici). Nikola Gavella et al., Stvarno pravo. Stjecanje prava vlasništva (Zagreb: Narodne novine, 2007.), 570.

34 Visoki trgovački sud Republike Hrvatske Pž 2631/2015 od 5. siječnja 2016., isto Pž 1034/2015 od 10. siječnja 2015. 
udjelu u smislu određenja iz članka 417. ZTD u vezi s odredbama ZBPO-a ${ }^{35}$ i Obza. ${ }^{36}$ Iz navedenoga proizlazi da poslovni udjel bračnim drugovima može pripadati samo zajedno i nepodijeljeno te da bračni drugovi nisu pojedinačno i svaki za sebe članovi društva pa se u knjigu poslovnih udjela uz poslovni udjel koji im zajednički pripada upisuje svaki od njih. Budući da se poslovni udjel stječe na temelju ugovora o prijenosu poslovnog udjela u obliku javnobilježničkog akta ili privatne isprave koju potvrđuje javni bilježnik, riječ je o stjecanju položaja ovlaštenika na jednom poslovnom udjelu koji drži jedan bračni drug, a nije riječ o stjecanju vlasništva polovice poslovnih udjela. ${ }^{37}$

Obz nema posebnih odredaba o razvrgnuću i diobi bračne stečevine, pa se primjenjuju odredbe stvarnog prava. ${ }^{38}$ Svaki bračni drug ima pravo na razvrgnuće suvlasništva u svako doba, osim: ako bi to bilo na štetu drugoga bračnog druga, odnosno u nevrijeme koje je privremene naravi ili kad je razvrgnuće ograničeno zakonom ili ako je bračni drug očitovanjem svoje volje sam ograničio pravo na razvrgnuće suvlasništva. ${ }^{39}$ Isto se može provesti sporazumno ili sudski, međutim treba uzeti u obzir posebnosti ZTD kao lex specialis. Za podjelu poslovnog udjela u društvu s ograničenom odgovornošću potrebna je odluka skupštine o podjeli poslovnog udjela. ${ }^{40}$ Izmjenama i dopunama ZTD-a iz 2009., ${ }^{41}$ podjela poslovnog udjela je uvijek moguća. Kod tužbi radi utvrđenja i podjele bračne stečevine treba imati na umu da sud nije ovlašten dijeliti poslovne udjele. Ovo zakonsko ograničenje utječe na odluke suda u sporovima radi utvrđenja bračne stečevine na poslovnom udjelu kada se tužbenim zahtjevom traži donošenje presude da se podijeli poslovni udjel koji drži jedan bračni drug. Analizom sudskih odluka dolazi se do zaključka da sudovi odbijaju zahtjeve za podjelu poslovnog udjela. Pritom je također bitno za primijetiti da sudovi prihvaćaju tužbene zahtjeve da su bračni drugovi ovlaštenici na jednom ili više poslovnih udjela u trgovačkom društvu. ${ }^{42}$ Okolnost da podjela nije moguća bez suglasnosti člana društva čiji se poslovni udjel dijeli, jer je riječ o raspolaganju poslovnim udjelom, a to zahtijeva i volju člana društva da se taj udjel podijeli, također govori u prilog da sud ne bi svojom odlukom mogao zamijeniti odluku skupštine društva, budući da u sporovima radi utvrđivanja i podjele poslovnog udjela kao bračne stečevine, takve suglasnosti u pravilu nema (tuženik se protivi tužbenom zahtjevu). ${ }^{43} \mathrm{U}$ tom smislu, tek nakon prijave prijenosa poslovnog udjela društvu bračni drug mogao bi

35 Čl. 271. i 279. (285.) ZBPO.

36 Čl. 249. Obz.

37 Visoki trgovački sud Republike Hrvatske Pž 4469/2017 od 17. prosinca 2019.

38 Čl. 47.-56. ZV.

39 Čl. 47. st. 1. ZV.

40 Čl. 441. st. 1. t. 5. ZTD. Više o odluci o podjeli poslovnog udjela vidi Barbić, Pravo društava. Knjiga 2. Svezak 2, 100.

41 Narodne novine, br. 137/09., ukinuta je odredba čl. 416. u kojoj su bila propisana ograničenja o podjeli poslovnog udjela. Više o razlozima ukidanja odredbe 416. ZTD u: Jakša Barbić, Zakon o trgovačkim društvima s uvodnim objašnjenjima, pregledom usklađenosti s europskim pravom i abecednim kazalom, 5. izmijenjeno izd. (Zagreb: Organizator, 2010.), 58.

42 Visoki trgovački sud Republike Hrvatske Pž 3111/2016 od 1. rujna 2016. i Pž-2631/2015 od 5. siječnja 2016.

43 Visoki trgovački sud Republike Hrvatske Pž 929/2015 od 6. studenog 2018. 
početi ostvarivati upravljačka i imovinska prava u društvu. Činjenica samog utvrđenja da je poslovni udjel bračna stečevina nije dostatna. Čak i ako bude utvrđeno da je poslovni udjel bračna stečevina, sve dok ne dođe do razvrgavanja zajednice prava nad tim udjelom (dogovor ili dioba), samo jedan bračni drug može ostvarivati prava koja proizlaze iz poslovnog udjela. ${ }^{44}$ Kako bi bračni drug koji nije upisan u knjigu poslovnih udjela kao član društva, mogao (početi) ostvarivati svoje prava kao člana društva, prvo je potrebno da se osim u knjigu poslovnih udjela upiše i u sudski registar. To proizlazi iz odredbe ZTD-a prema kojoj je član društva onaj koji je upisan u knjigu poslovnih udjela i o čijem je članstvu u društvu obaviješten registarski sud. ${ }^{45}$

U sudskoj se praksi postavilo i pitanje je li promjena vrijednosti poslovnog udjela tijekom trajanja bračne zajednice bračna stečevina, iako je poslovni udjel stečen prije sklapanja braka pa predstavlja vlastitu imovinu bračnog druga. Zauzeto je pravno shvaćanje da imovina, pa tako i zajednička imovina bračnih drugova, može biti samo poslovni udjel, kao samostalna pravna kategorija. Eventualne razlike između nominalne vrijednosti poslovnog udjela i njegove tržišne vrijednosti nisu posebna pravna kategorija koja bi mogla biti predmet utvrđivanja u braku stečene imovine. ${ }^{46}$

\section{PARNIČNI POSTUPCI RADI UTVR円IVANJA BRAČNE STEČEVINE NA POSLOVNOM UDJELU}

Pravo društava kao nužan preduvjet za stjecanje članstva u društvu predviđa upis u knjigu poslovnih udjela. ${ }^{47}$ Prema pravu društava jedini ovlašteni za ostvarivanje članskih prava koja proizlaze iz poslovnog udjela je član društva upisan u knjigu poslovnih udjela i sudski registar, odnosno formalno upisani bračni drug. U praksi se pojavljuje problem kako praktično vezano za poslovni udjel primijeniti normu Obz-a da su bračni drugovi suvlasnici svega što ulazi u predmet bračne stečevine na jednake dijelove, počevši od stvarne nadležnosti sudova.

Razlika u pravnoj osnovi stjecanja poslovnog udjela u sudskoj praksi dovodi do različitih stajališta. S jedne je strane jedan bračni drug, član društva kojeg je stekao poslovni udjel na temelju ugovora o osnivanju društva, odnosno mogao je biti stranka ugovora o prijenosu poslovnog udjela ako ga je kupio i stekao od treće osobe. Taj je bračni drug upisan kao imatelj poslovnog udjela i član društva u knjizi poslovnih udjela. S druge strane, drugi bračni drug taj je isti poslovni udjel stekao ex lege i nije imatelj poslovnog udjela niti je član društva niti je upisan u knjizi poslovnih udjela jer se članom društva smatra samo onaj tko je upisan u knjizi poslovnih udjela i o čijem je članstvu u društvu obaviješten registarski sud.

\subsection{Nadležnost}

U praksi se sudova postavilo pitanje koji je sud stvarno nadležan za odlučivanje

44 Jelinić, Bračna stečevina u kontekstu Zakona o trgovačkim društvima, 132.

45 Čl. 411. st. 1. ZTD.

46 Vrhovni sud Republike Hrvatske Rev 1176/2010-2 od 11. prosinca 2012.; isto Visoki trgovački sud Republike Hrvatske Pž 3111/2016 od 1. rujna 2016.

47 Upis u knjigu poslovnih udjela je konstitutivan - čl. 411. st. 2. ZTD. 
u sporu radi utvrđenja poslovnog udjela bračnom stečevinom i s tim u vezi. Je li riječ o odluci o raspolaganju članstvom u trgovačkom društvu ili se primjenom propisa obiteljskog prava utvrđuje je li poslovni udjel prema zakonu bračna stečevina?

Pravno shvaćanje Visokog trgovačkog suda Republike Hrvatske koje je zauzeto bilo je da u parnici u kojoj je tužbeni zahtjev usmjeren na utvrđenje kako je poslovni udjel bračna stečevina, sud neće odlučivati o raspolaganju članstvom u trgovačkom društvu, već primjenom propisa obiteljskog prava, posebno Obz-a, utvrđivati je li poslovni udjel prema zakonu bračna stečevina. Za suđenje o tom zahtjevu stvarno je nadležan općinski sud. ${ }^{48}$ To obrazlaže tako da pojam raspolaganja članstvom i članskim pravima podrazumijeva dragovoljno raspolaganje imatelja poslovnog udjela otuđenjem ili opterećenjem.

Vrhovni sud Republike Hrvatske u svojim odlukama zauzima drukčije pravno shvaćanje te navodi da ako je predmet spora utvrđenje da su tužiteljica i tuženik suvlasnici svaki u polovici poslovnog udjela trgovačkog društva i nalaže se tuženiku da tužiteljici izda ispravu podobnu za upis njenog suvlasničkog dijela na navedenom poslovnom udjelu, za suđenje je nadležan trgovački sud. Navedenim zahtjevom tužiteljice dira se u prava članova trgovačkog društva, pa je u tom sporu nadležan suditi trgovački sud. ${ }^{49}$ Isto tako, tužbenim zahtjevom kojim tužitelj traži da mu bračni drug koji je upisan u sudskom registru i u knjizi poslovnih udjela kao član društva plati odgovarajući dio isplaćene mu dividende, jer je na temelju okolnosti da je poslovni udjel dio bračne stečevine suovlaštenik na tom udjelu, dira se u prava članova društva, pa je za njegovo rješavanje nadležan trgovački sud. ${ }^{50}$

\subsection{Tužba i tužbeni zahtjev}

Poslovni udjeli u društvima stečeni tijekom braka ulaze u bračnu stečevinu i ako je jedan bračni drug član društva, a nije sklopljen predbračni ugovor kojim se uređuje pravni režim imovine stečene $u$ braku, treba smatrati da je povezan s poslovnim udjelom povjerenik drugoga bračnog druga u pogledu njegova udjela u imovni stečenoj u braku. ${ }^{51}$ Taj bračni drug može zahtijevati da se utvrdi njegovo sudjelovanje u poslovnom udjelu, tako da je zajedno s drugim bračnim drugom ovlaštenik tog udjela. Tada bi sa stajališta društva poslovni udjel nepodijeljeno pripadao većem broju osoba (bračnim drugovima) kao ovlaštenicima i primjenjivao bi se pravni režim koji vrijedi u tom slučaju. ${ }^{52}$

\subsubsection{Stranke u postupku - ovlaštenici na poslovnom udjelu}

48 Pravno shvaćanje zauzeto na sjednici sudaca Visokog trgovačkog suda Republike Hrvatske od 19. lipnja 2008.

49 Vrhovni sud Republike Hrvatske Gr1 137/06-2 od 13. travnja 2006., Gr1 38/09-2 od 24. veljače 2009., Gr1 526/14-2 od 8. prosinca 2014. i dr.

50 Visoki trgovački sud Republike Hrvatske Pž 6552/18 od 19. prosinca 2018.

51 Barbić, Pravo društava. Knjiga 2. Svezak 2, 106.

52 Visoki trgovački sud Republike Hrvatske Pž 1496/2015 od 16. listopada 2018. 
Aktivno legitimirana stranka je bračni drug koji tvrdi da je poslovni udjel u nekom društvu predmet bračne stečevine. Pasivno legitimirana stranka je drugi bračni drug koji je upisani imatelj poslovnog udjela. Društvo čiji su poslovni udjeli predmet rasprave u parničnom postupku nije stranka u postupku ni na aktivnoj ni na pasivnoj strani. ${ }^{53}$

Do sporova pred sudom dolazi jer jedan bračni drug ne želi priznati drugom bračnom drugu to pravo, smatrajući najčešće da je riječ o vlastitoj imovini stečenoj ili prije osnivanja bračne zajednice ili novcem koji nije stečen radom već nasljeđivanjem, darovanjem od članova obitelji. U tu se svrhu predlažu razni osobni dokazi koji su uglavnom subjektivni, naklonjeni onom bračnom drugu koji ih je predložio radi dokazivanja. Ako bračni drug, koji je upisan kao član društva u knjizi poslovnih udjela, ne pristane da se drugi bračni drug upiše u knjigu poslovnih udjela kao ovlaštenik, tada to svoje pravo drugi bračni drug može ostvariti tužbom..$^{54}$ Tužbeni zahtjev treba biti točan i jasan, što često izostaje. ${ }^{55}$ Kada je bračni drug upisan kao imatelj poslovnog udjela, primjerice nominalnog iznosa od $20.000 \mathrm{kn}$, a tužbenim zahtjevom drugi bračni drug traži da se utvrdi kako mu/joj pripada poslovni udjel određenoga nominalnog iznosa od $10.000 \mathrm{kn}$, to nije moguće. To bi značilo da je došlo do podjele poslovnog udjela. Za podjelu poslovnog udjela potrebna je odluka skupštine društva što je ovdje izostalo. ${ }^{56}$ Tuženik ima jedan poslovni udjel od 20.000 kn u opisanom primjeru. Tuženik nema dva poslovna udjela svaki nominalnog iznosa od $10.000 \mathrm{kn} .{ }^{57}$ Sudskim se putem može tražiti promjena onoga što je upisano u knjizi poslovnog udjela i u sudskom registru u pogledu toga tko je imatelj poslovnog udjela, pa prema tome i član društva, osobito kada je riječ o bračnoj stečevini. ${ }^{58}$

Tužbeni zahtjev bi trebao ponajprije obuhvatiti utvrđenje da je točno određeni poslovni udjel bračna stečevina bračnih drugova, tužitelja i tuženika (deklaratorni dio), kao i utvrđenje da je bračni drug ovlaštenik na poslovnom udjelu u točno određenom dijelu (primjerice i najčešće u polovici, deklaratorni dio). Uz to, tužbenim je zahtjevom potrebno tražiti kondemnatornu pravnu zaštitu kojom se nalaže bračnom drugu koji je upisan kao član društva i imatelj poslovnog udjela da bračnom drugu koji nije upisan kao član društva i imatelj poslovnog udjela, a stekao je poslovni udjel na temelju zakona, izda ispravu podobnu za upis u knjigu poslovnih udjela trgovačkog društva, kao i ispravu podobnu za upis kod nadležnog suda, kao ovlaštenika na tom poslovnom udjelu u točno određenom dijelu ili će u protivnom navedeno zamijeniti presuda. ${ }^{59}$ Stoga bi sadržajno dio tužbenoga zahtjeva bio i ugovor o prijenosu poslovnih

53 Visoki trgovački sud Republike Hrvatske Pž 5432/2018 od 16. srpnja 2020.; isto Pž 2823/2019 od 30. svibnja 2019.

54 Barbić, Pravo društava. Knjiga 2. Svezak 2, 108.

55 Visoki trgovački sud Republike Hrvatske Pž-3111/2016 od 1. rujna 2016.

56 Barbić, Pravo društava. Knjiga 2. Svezak 2, 106; Visoki trgovački sud Republike Hrvatske broj Pž-3111/2016 od 1. rujna 2016.

57 Visoki trgovački sud Republike Hrvatske Pž 3073/2013 od 19. listopada 2016.

58 Barbić, Pravo društava. Knjiga 2. Svezak 2, 107.

59 Izmjenama i dopunama ZTD-a iz 2019., Narodne novine, br. 40/19. u članku 412. dodano je da je za prijenos poslovnog udjela potreban (ugovor sklopljen u obliku javnobilježničkog akta ili privatne isprave koju potvrdi javni bilježnik ili) sudska odluka koja zamjenjuje takav ugovor. 
udjela sa svim sastavnim dijelovima. Izdavanje isprave podobne za upis u knjigu poslovnih udjela ne može se poistovjetiti s ugovorom u obliku javnobilježničkog akta ili privatne isprave koju potvrdi javni bilježnik, a na temelju kojih se može izvršiti prijenos poslovnog udjela u skladu s odredbom članka 412. ZTD-a. Isprava koja je predmet tužbenog zahtjeva ima značenje jednostrane izjave, dok ugovor u obliku javnobilježničkog akta ili privatne isprave koju potvrdi javni bilježnik imaju značenje dvostrano obveznog ugovora. ${ }^{60}$

Tijekom postupka strana koja tvrdi da je predmetni poslovni udjel bračna stečevina treba to i dokazati i na tom je bračnom drugu teret dokazivanja. Ako je poslovni udjel stečen prije nastanka bračne zajednice ili je stečen na temelju drugoga pravnog osnova, bračni drug koji tvrdi treba to i dokazati. Ako je riječ o teretu dokazivanja govori se o dostavljanju adekvatnih dokaza tijekom prvostupanjskog postupka. ${ }^{61}$

\subsubsection{Raspolaganje poslovnim udjelom (bez suglasnosti bračnoga druga)}

Pravni posao koji jedan bračni drug zaključi u vezi s bračnom stečevinom bez potrebne suglasnosti drugoga bračnog druga, može osporavati drugi bračni drug, osim ako je druga ugovorna strana bila u dobroj vjeri. Ako je ugovorna strana toga bračnog druga u dobroj vjeri, drugi bračni drug ne može osporiti pravni posao i može tražiti samo naknadu štete od bračnog druga koji je otuđio poslovni udjel bez suglasnosti. Bračni drug tužbenim zahtjevom traži utvrđenje ništetnosti ugovora o prijenosu poslovnih udjela budući da je drugi bračni drug sam raspolagao poslovnim udjelom koji je bračna stečevina (jer drugi bračni drug koji je stekao poslovni udjel na temelju zakona nije bio upisan u knjizi poslovnih udjela u trenutku prijenosa). Kada (i ako) sud pravomoćno utvrdi ništetnost takvog ugovora, treba sagledati i nastale posljedice. Zakonom o obveznim odnosima u slučaju ništetnosti ugovora propisano je da je svaka ugovorna strana dužna vratiti drugoj sve što je primila na temelju ništetnog ugovora ili (ako to nije moguće ili se narav ispunjenog protivi vraćanju) dati odgovarajuću naknadu u novcu, prema cijenama u vrijeme donošenja sudske odluke. ${ }^{62}$ Osoba koja je kriva za sklapanje ništetnog ugovora odgovorna je i svom suugovaratelju za štetu koju trpi zbog ništetnosti ugovora, ako on nije znao ili nije morao znati za uzrok ništetnosti. Pritom treba voditi računa o zastarnim rokovima kod naknade štete. Druga je situacija kada bračni drug, koji je imatelj poslovnog udjela u društvu, osnuje drugo društvo s vlastitim sredstvima, sredstvima koja ne ulaze u pravni režim bračne stečevine. Tada bračni drug prebacuje svu imovinu (pa čak i poslovne udjele) iz (ranijeg) društva na to novoosnovano društvo. To novoosnovano društvo obično je sličnog naziva tvrtke kao ranije društvo i vrlo je često registrirano na istoj adresi. Tako imovina novog društva raste, a staroga, koje je predmet bračne stečevine, se smanjuje. Time se nanosi šteta bračnom drugu koji nije upisan u knjigu poslovnih udjela niti u sudski registar. Tada u pravilu dolazi do stečaja društva koje je osnovano tijekom braka čiji bi poslovni

60 Visoki trgovački sud Republike Hrvatske Pž 4469/2017od 17. prosinca 2019.

61 Ustavni sud Republike Hrvatske broj U-III-2027/2017 od 11. prosinca 2019.

62 Čl. 323. Zakona o obveznim odnosima, Narodne novine, br. 35/05., 41/08., 125/11., 78/15., 29/18. (dalje: ZOO). 
udjel ušao u bračnu stečevinu. Bračni drug koji nije upisan kao član društva nema načina ovo spriječiti, osim zahtijevati naknadu štete uz dokazivanje svih pretpostavki naknade štete prema ZOO-u.

Iz svega navedenog proizlazi da ako bračni drug tijekom bračne zajednice stekne poslovni udjel u trgovačkom društvu s ograničenom odgovornošću, tada zapravo stekao tek polovicu toga poslovnog udjela. ${ }^{63}$ Naime, oba bračna druga postaju članovi društva i zajednički imatelji poslovnog udjela u jednakim dijelovima. Međutim, što je s očitovanjem volje ugovornih strana pri takvom prijenosu poslovnog udjela? Što ako drugi bračni drug nije očitovao svoju volju i ne želi biti imatelj u polovici dijela toga poslovnog udjela? Postaje li on svejedno član društva, suovlaštenik na poslovnom udjelu?

Do sporova povezanih s bračnom stečevinom najčešće dolazi zbog (pogrešne) premise da je imovina društva s ograničenom odgovornošću, čiji je član i imatelj poslovnog udjela bračni drug (tuženik), bračna stečevina bračnih drugova. Kao što je rečeno riječ je o pogrešnoj premisi ${ }^{64}$ Bračni drug koji nije upisan u knjigu poslovnih udjela smatra da ako društvo ima imovinu da je navedeno bračna stečevina. Bitno je razlikovati imovinu društva, kao jednoga pravnog subjekta, od imovine bračnoga druga, kao drugog subjekta. ${ }^{65}$

\subsubsection{Poslovni udjel kao predmet bračne stečevine u brisanim društvima}

Otvaranjem stečajnog postupka nad društvom ne prestaje članstvo u društvu. Pravna je posljedica otvaranja stečajnog postupka da upravljačko pravo člana društva prelazi s člana uprave na stečajnog upravitelja. ${ }^{66}$ Imovinsko pravo člana društva i dalje postoji sve dok postoji mogućnost da se ostatak stečajne mase eventualno podijeli članovima društva (nakon namirenja vjerovnika). Postoji i pravni interes za utvrđenje da je poslovni udjel bračna stečevina u društvu nad kojim je otvoren stečaj i tijekom stečajnog postupka. Brisanjem pravne osobe iz sudskoga registra pravna osoba prestaje postojati i prestaje poslovni udjel zajedno s članstvom. Ako ostane višak stečajne mase za podjelu, tada je odlučno tko je tijekom brisanja društva bio član društva. Zaključuje se da bi predmet bračne stečevine mogao biti poslovni udjel samo društva koje postoji. U odnosu na bračnu stečevinu na poslovnom udjelu u trgovačkom društvu koje je brisano nakon što je nad tim društvom proveden stečajni postupak, nema poslovnih udjela koji bi predstavljali bračnu stečevinu. ${ }^{67}$ Isto je i s društvom koje je pripojeno i brisano zbog pripajanja drugom trgovačkom društvu. ${ }^{68}$ Nakon što je trgovačko društvo pripojeno drugom trgovačkom društvu, više nema poslovnih udjela pripojenoga trgovačkog društva pa nije moguće utvrditi poslovne

63 Visoki trgovački sud Republike Hrvatske Pž 855/2014 od 13. rujna 2017.

64 Jakša Barbić, Pravo društava. Knjiga 1. Opći dio, 3. izmijenjeno i dopunjeno izd. (Zagreb: Organizator, 2008.), 40.

65 Vrhovni sud Republike Hrvatske Rev 2128/2010-2 od 18. prosinca 2012.; Visoki trgovački sud Republike Hrvatske Pž 2575/2017 od 8. svibnja 2018.

66 Čl. 159. st. 1. Stečajnog zakona - Narodne novine, br. 71/15., 104/17.

67 Visoki trgovački sud Republike Hrvatske broj Pž 2763/2018 od 4. svibnja 2020.

68 Visoki trgovački sud Republike Hrvatske broj Pž 2763/2018 od 4. svibnja 2020. 
udjele na društvu koje ne postoji, a niti je moguće izdati ispravu podobnu za upis suovlaštenika na takvom nepostojećem poslovnom udjelu.

\subsubsection{Dobit društva s ograničenom odgovornošću kao predmet bračne stečevine}

U predmetu trgovačkoga suda bračni drug je tužbom tražio da sud utvrdi da u bračnu stečevinu ulazi dobit društva te naloži tuženiku isplatiti određeni postotak dobiti tog društva. ${ }^{69} \mathrm{~S}$ pbzirom na pravnu prirodu postavljenoga tužbenog zahtjeva (imovinska prava povezana s utvrđenjem da u bračnu stečevinu ulazi dobit društva) tek nakon što se u odnosu na tužbeni zahtjev u drugom parničnom predmetu utvrdi da je poslovni udjel koji u tom društvu ima tuženik bračna stečevina stranaka te da je na skupštinama društva kroz sporno razdoblje donesena odluka o načinu na koji će se upotrijebiti ostvarena dobit, odnosno pripadajuća prava članova društva, moći će se odlučiti o (ne)osnovanosti tužbenog zahtjeva te je postupak prekinut. Onaj tko je član društva u vrijeme kad je skupština društva donijela odluku o isplati dobiti stječe pravo na isplatu dobiti na temelju te odluke skupštine, bez obzira na raspolaganje poslovnim udjelom. Raspolaže li član društva prije toga poslovnim udjelom pa je stjecatelj poslovnog udjela član društva za vrijeme donošenja odluke o isplati dobiti, ona pripada njemu, a ne prethodnom članu društva. Raspolaže li član društva koji je bio član društva u vrijeme donošenja odluke skupštine poslovnim udjelom, stjecatelj ne stječe i tražbinu na isplatu dobiti koja ostaje članu društva koji je bio član u vrijeme donošenja odluke. Kod toga valja imati na umu da se članstvo u društvu stječe podnošenjem društvu zahtjeva za upis u knjigu poslovnih udjela s prilozima podobnim za upis. ${ }^{70}$ Pravo člana društva na isplatu godišnje dobiti i zadržane dobiti iz ranijih godina u mjeri u kojoj to nije isključeno zakonom, društvenim ugovorom ili odlukom članova o upotrebi dobiti, temeljno je pravo imatelja poslovnog udjela. Ono proizlazi isključivo iz njegova članstva i nema nikakve veze je li taj imatelj poslovnog udjela u radnom odnosu u društvu ili ne. Tako osoba koja je imatelj poslovnog udjela ima, razmjerno veličini svog udjela, jednako pravo na isplatu dobiti kao i osoba koja ima poslovni udjel iste veličine, ali ujedno i radi u tom društvu. To dodatno ukazuje da nije moguće promatrati povećanje temeljnoga kapitala iz zadržane dobiti s radom imatelja poslovnog udjela na temelju ugovora o radu u tom društvu. ${ }^{71}$

\subsubsection{Tužbeni zahtjevi - izazovi u praksi}

Izazov koji se javlja u praksi je, primjerice, da jedan od bračnih drugova umre, a poslovni udjel (stečen radom za vrijeme trajanja bračne zajednice) upisan je na drugoga bračnog druga. Nakon smrti zakonski nasljednici, zajednička djeca, tužbenim zahtjevom traže, među ostalim, utvrđenje da je predmetni poslovni udjel u društvu bračna stečevina. Djeca kao zakonski nasljednici imala bi pravni interes za utvrđenje da je poslovni udjel bračna stečevina pokojnoga bračnog druga i drugoga bračnog

69 Visoki trgovački sud Republike Hrvatske rješenje broj Pž 4422/2014 od 13. ožujka 2017.

70 Visoki trgovački sud Republike Hrvatske Pž 3851/2018 od 18. lipnja 2018.

71 Vrhovni sud Republike Hrvatske Rev 1176/10 od 11. prosinca 2012.; Visoki trgovački sud Republike Hrvatske Pž 2494/2019 od 2. listopada 2020. 
druga. U konkretnom slučaju bi imali osobu koja podnosi tužbu radi utvrđenja bračne stečevine koja sama nije sudionik tog odnosa, bračne zajednice. Da bi ta osoba bila tužitelj i aktivno legitimirana strana, potrebno je izričito ovlaštenje određeno zakonom na tu mogućnost ili pri podnošenju tužbe dokazati svoj konkretan pravni interes. Tužbom radi utvrđenja bračne stečevine mogu se štititi samo prava uknjižena u knjizi poslovnog udjela što je konkretno poslovni udjel upisan na drugoga bračnog druga. Stoga zakonski nasljednici nakon pokojnoga bračnog druga (pokojni bračni drug je zapravo suovlaštenik na poslovnom udjelu na temelju zakona, ali pritom nije upisan u knjizi poslovnih udjela) nisu aktivno legitimirani za podnošenje takve tužbe. To međutim nije zapreka da zakonski nasljednici nakon pokojnoga bračnog druga koji nije upisan u knjigu poslovnih udjela kao suovlaštenik na poslovnom udjelu, svoja prava koja proizlaze iz poslovnog udjela štite u posebnoj parnici zahtijevajući dozvolu upisa svoga prava u knjizi poslovnih udjela. ${ }^{72}$ Pri tome valja naglasiti da sudovi daju pravo, priznaju pravni interes i aktivnu legitimaciju za utvrđenje ništetnosti odluka skupštine društva s ograničenom odgovornošću bračnom drugu koji nije upisan u knjigu poslovnih udjela. ${ }^{73}$

\section{IZVANPARNIČNI POSTUPCI RADI UTVRĐENJA BRAČNE STEČEVINE NA POSLOVNOM UDJELU}

Bračni drug koji traži utvrđenje bračne stečevine na poslovnom udjelu može koristiti i dodatne mehanizme zaštite tijekom parničnog postupka u kojem tužbenim zahtjevom traži utvrđenje bračne stečevine na poslovnom udjelu kao predmetu bračne stečevine. Tako se uz tužbu podnosi i prijedlog za određivanje privremene mjere u cilju osiguranja tražbine sukladno odredbama Ovršnog zakona. ${ }^{74}$ Opća pretpostavka za prijedlog, a time i za donošenje rješenja o određivanje privremene mjere, vjerojatnost je konkretnoga spornog odnosa između stranaka kao objekt osiguranja. Alternativne pretpostavke za određivanje privremene mjere bile bi: ako je to nužno radi sprječavanja nastanka nenadoknadive štete, ili ako je to nužno radi sprječavanja nasilja, ili ako je potrebno radi osiguranja pravnoga reda. ${ }^{75}$

Osiguranje tražbine mjerom osiguranja služi svojevrsnom privremenom očuvanju postojećeg stanja, kako bi predlagatelj čija se tražbina osigurava, u slučaju uspjeha u sporu, mogao ostvariti svoju tražbinu. ${ }^{76}$ Bračni drug koji nije član društva može tražiti da sud odredi privremenu mjeru radi osiguranja (ne)novčane tražbine

72 Europski sud za ljudska prava priznaje da se i legitimna očekivanja stranaka uz određene pretpostavke moraju smatrati imovinom pod zaštitom članka 1. Protokola br. 1. Konvencije za zaštitu ljudskih prava i temeljnih sloboda, Narodne novine - Međunarodni ugovori, br. 18/97., 6/99. - pročišćeni tekst, 8/99. - ispravak, 14/02. i 1/06. (dalje: Konvencija), koji uređuje zaštitu vlasništva; Odluka o dopuštenosti zahtjeva u predmetu Gavella protiv Hrvatske od 11. srpnja 2006., zahtjev br. 33244/02.

73 Visoki trgovački sud Republike Hrvatske Pž 3647/13-4 od 26. lipnja 2013.

74 Ovršni zakon, Narodne novine, br. 112/12., 25/13., 93/14., 55/16., 73/17., 131/20. (dalje: OZ).

75 Čl. 340. OZ.

76 Visoki trgovački sud Republike Hrvatske rješenje broj Pž 2597/17-2 od 28. travnja 2017. 
protiv protivnika osiguranja zabrane otuđenja i opterećenja poslovnog udjela. ${ }^{77} \mathrm{Za}$ ocjenu toga dovoljno je da postoji vjerojatnost, a ne traži se izvjesnost, riječ je o mogućnosti da se takvo uvjerenje poklapa sa stvarnošću. Kod određivanja privremene mjere protivnik osiguranja i dalje ostvaruje svoj članski položaj u društvu, a privremena mjera služi svojevrsnom zamrzavanju postojećeg stanja kako bi tužitelj, ako uspije u sporu mogao ostvariti svoju (ne)novčanu tražbinu, utvrđenje da je suimatelj poslovnog udjela i da ga se kao takvog upiše u knjigu poslovnih udjela. ${ }^{78}$

Kako je poslovni udjel jedinstvena cjelina koja pripada jednoj osobi ili većem broju njih zajedno, predmetom osiguranja privremenom mjerom zabrane otuđenja $\mathrm{i}$ opterećenja, pa i ovrhe, može biti samo cijeli poslovni udjel, a ne neki njegov idealni dio. Tako jedan bračni drug ne može tražiti zabranu otuđenja i opterećenja na idealnoj polovini poslovnog udjela, nego cijelog poslovnog udjela u odnosu na bračnog druga koji je upisan u knjizi poslovnih udjela kao član društva. ${ }^{79}$

Bračni drug člana društva ne bi mogao na temelju činjenica da poslovni udjel ulazi u njihovu bračnu stečevinu ishoditi određenje privremene mjere $u$ obliku postavljanja privremene uprave društva u kome je njegov bračni drug član. Naime, poslove društva vodi uprava koju društvo ima, ako je nema ili da uprava nema potreban broj članova može se u propisanom postupku jedino tražiti postavljanje privremenog upravitelja. ${ }^{80}$ Nije moguća ni privremena mjera kojom bi se poslovni udjel u društvu u kome je član bračni drug povjeriti na upravu trećoj osobi, jer društvo ima članove kojima pripadaju udjeli i to im se ne može oduzeti privremenom mjerom. ${ }^{81}$

Ako poslovni udjel ulazi u bračnu stečevinu, bračni drugovi kao suovlaštenici na tom udjelu mogu pravo na dividendu koju daje poslovni udjel (kao i sva ostala prava) ostvarivati samo zajednički. Stoga bi ipak bilo moguće odrediti privremenu mjeru zabrane isplate dividende bračnom drugu koji je upisan u knjizi poslovnih udjela kao član društva dok se ne završi parnica kojom drugi bračni drug traži utvrđenje da je na temelju bračne stečevine suimatelj poslovnog udjela ${ }^{82}$ Predlagatelj osiguranja morao bi dokazati da je skupština društva donijela odluku o isplati dividende iz ostvarene dobiti, u kojem iznosu i koliki dio dividende otpada na poslovni udjel koji čini bračnu stečevinu te eventualni dogovor bračnih drugova o zajedničkom raspolaganju pravima iz tog udjela. ${ }^{83} \mathrm{Uz}$ sve navedeno valja reći da bračni drug nema tražbinu s osnova dobiti, jer pravo na dobit ostvaruje član društva u smislu odredbe čl. 411. st. 1.ZTD-a, a predlagatelj (obično) nije upisan kao član društva. ${ }^{84}$ Prije je toga potrebno tražbinu označiti, što se čini da je najveći problem strankama u postupku osiguranja ${ }^{85}$

77 Barbić, Pravo društava. Knjiga 2. Svezak 2, 106.

78 Visoki trgovački sud Republike Hrvatske Pž 2597/17-2 od 28. travnja 2017.

79 Barbić, Pravo društava. Knjiga 2. Svezak 2, 107; Visoki trgovački sud Republike Hrvatske broj Pž 3111/2016 od 1. rujna 2016.; isto i Pž 2155/2018 od 3. travnja 2018.

80 Barbić, Pravo društava. Knjiga 2. Svezak 2, 108.

81 Visoki trgovački sud Republike Hrvatske Pž 5137/17-2 od 28. kolovoza 2017.

82 Barbić, Pravo društava. Knjiga 2. Svezak 2, 108.

83 Visoki trgovački sud Republike Hrvatske Pž 2911/2018 od 18. svibnja 2018.

84 Visoki trgovački sud Republike Hrvatske Pž 2911/2018 od 18. svibnja 2018.; isto Pž 3851/2018 od 18. lipnja 2018.

85 Visoki trgovački sud Republike Hrvatske Pž 7509/2017 od 5. siječnja 2018.; Pž 1927/2018 od 4. travnja 2018. 
Radi zaštite prava, uz tužbu se može podnijeti i zahtjev za zabilježbu spora prema pravilima Zakona o sudskom registru. ${ }^{86}$ Zabilježba spora je upis kojim se u sudskom registru, kao javnoj knjizi, čini vidljivim da se glede nekog određenog pravnog odnosa pred sudom ili drugim nadležnim tijelom vodi postupak čiji bi ishod mogao utjecati na određeni upis u sudski registar. Svrha je upisa zabilježbe spora da se nakon njene provedbe nitko neće moći opravdavati da nije znao ni mogao znati da se glede određenog pravnog odnosa vodi takav postupak. U svojim odlukama Visoki trgovački sud Republike Hrvatske zauzeo je stajalište da je zabilježba spora dopuštena kada je predmet spora zahtjev za utvrđenje da su poslovni udjeli u nekom društvu bračna stečevina i da je tužitelj ovlaštenik na tim poslovnim udjelima. Predujmljivanje troškova objave upisa zabilježbe spora u sudskom registru nije pretpostavka dopuštanja zabilježbe spora, jer objavom na mrežnoj stranici na kojoj se nalazi sudski registar ne nastaju stvarni troškovi objave pa se troškovi ne mogu ni predujmiti. ${ }^{87}$ Budući da je zabilježba spora upis činjenice da je u tijeku određena parnica, na zabilježbu spora ne utječe je li tužbeni zahtjev utemeljen ili ne. ${ }^{88}$

\section{ZAKLJUС̆ AK}

Poslovne udjele koje je (formalnopravno) stekao samo jedan od bračnih drugova, imovina su oba bračna druga. Stvarni su vlasnici, suovlaštenici oba bračna druga. Vrijednost poslovnog udjela bračna je stečevina jer je nastao kao posljedica ulaganja novca (stvari ili prava) zarađenog tijekom bračne zajednice. Pravna sredstva bračnoga druga koji nije upisan u knjigu poslovnih udjela i sudski registar, ako bračni drug koji je (jedini) upisan u knjigu poslovnih udjela i sudski registar prikrije poslovni udjel ili jednostavno ne želi podijeliti poslovni udjel u trgovačkom društvu pri diobi bračne stečevine, ovisi o načinu kako je upisani bračni drug to napravio. Ako je upisani bračni drug sklopio ugovor o prijenosu poslovnog udjela u trgovačkom društvu s trećom osobom, bračni drug koji nije upisan u knjigu poslovnih udjela i sudskom registru, može taj pravni posao pobijati tužbom ako treća osoba nije postupala u dobroj vjeri. Ako je upisani bračni drug prenio imovinu ili aktivnosti trgovačkog društva na drugo trgovačko društvo, bračni drug koji nije upisan može (samo) podnijeti tužbu protiv bračnoga druga za naknadu štete i pritom dokazati sve pretpostavke za naknadu štete.

Autorica stoga postavlja pitanje: što je s registrom stvarnih vlasnika? Ako su oba bračna druga stvarni vlasnici, oboje valja upisati u registar stvarnih vlasnika jer to zahtijeva Zakon o sprječavanju pranja novca i financiranja terorizma. Je li tako u praksi to bi mogao biti predmet nekoga novog istraživanja.

Provedena analiza pokazala je da, uz bogatu sudsku praksu u odnosu na bračnu stečevinu na poslovnom udjelu, pojedina pitanja povezana s poslovnim udjelom kao predmetom bračne stečevine su osobito sporna u sudskoj praksi. Riječ je o vrlo

86 Čl. 38.a Zakona o sudskom registru, Narodne novine, br. 1/95., 57/96., 1/98., 30/99., 45/99., 54/05., 40/07., 91/10., 90/11., 148/13., 93/14., 110/15., 40/19.

87 Pravno shvaćanje Visokog trgovačkog suda prihvaćenoj na sjednici održanoj 20. prosinca 2018.

88 Visoki trgovački sud Republike Hrvatske Pž 4447/2020 od 21. listopada 2020.; isto Pž 1361/2019 od 28. veljače 2019. 
emotivnim sporovima jer životna zajednica kao što je brak obuhvaća emotivnu zajednicu bračnih drugova koja se očituje i njihovoj bračnoj stečevini. Spor nastaje oko imovinskog dijela bračne zajednice. Bračni drugovi u to često uvlače djecu, što je negativna posljedica sukoba. Djeca tada zauzimaju strane, osobito ona punoljetna koja katkad i preuzimaju poslovne udjele u društvima, pa i funkcije članova uprave iako su stvarni vlasnici te imovine bračni drugovi, njihovi roditelji.

U praksi je katkad teško točno utvrditi jasnu granicu između bračne stečevine i vlastite imovine. Kako bi se izbjegle moguće nedoumice, osim bolje obaviještenosti, autorica zastupa pragmatični pristup. Ugovorno uređenje imovinskih odnosa bračnih drugova sklapanjem (pred)bračnog ugovora kojim će se urediti odnosi na postojećoj i/ ili budućoj imovini bračnih drugova. Pritom je nužno svakako koristiti pravnu pomoć. Ne bi trebalo isključiti ni mogućnost uređenja zakonskoga okvira za takve situacije.

\section{Knjige i članci:}

\section{LITERATURA}

1. Alinčić, Mira, Dubravka Hrabar, Dijana Jakovac-Lozić i Aleksandra Korać Graovac. Obiteljsko pravo. 3. izmijenjeno i dopunjeno izd., Zagreb: Narodne novine, 2007.

2. Barbić, Jakša. Pravo društava. Knjiga 1. Opći dio. 3. izmijenjeno i dopunjeno izd. Zagreb: Organizator, 2008.

3. Barbić, Jakša. Pravo društava. Knjiga 2: Društva kapitala. Svezak 1. i 2. 7. izmijenjeno i dopunjeno izd., Zagreb: Organizator, 2020.

4. Barbić, Jakša. Zakon o trgovačkim društvima s uvodnim objašnjenjima, pregledom uskladenosti s europskim pravom i abecednim kazalom. 5. izmijenjeno izd. Zagreb: Organizator, 2010.

5. Belaj, Vlado, „Bračna stečevina po Obiteljskom zakonu“, Zbornik Pravnog fakulteta Sveučilišta u Rijeci 23, br. 1 (2002): 179-200.

6. Bienenfeld, Josip, Snježana Frković, Olga Jeličić, Tatjana Josipović, Zdenka Koharić, Damir Kontrec, Damir Pahić i Petar Simonetti. Nekretnine kao objekti imovinskih prava: građevinsko zemljište, posebni dijelovi zgrada, objekti na pomorskom dobru: katastar $i$ zemljišne knjige. Zagreb: Narodne novine, 2007.

7. Čulinović-Herc, Edita, Sonja Marinac Rumora i Mihaela Braut Filipović. „Pravno uređenje odnosa članova u zatvorenim (closely held) društvima na primjeru hrvatskog društva s ograničenom odgovornošću“. Zbornik Pravnog fakulteta Sveučilišta u Rijeci 39, br. 1 (2018.): 45-90.

8. Gavella, Nikola, Tatjana Josipović, Igor Gliha, Vlado Belaj i Zlatan Stipković. Stvarno pravo. Zagreb: Narodne novine, 2007.

9. Gorenc, Vilim, Zvonimir Slakoper, Vladimir Filipović i Vlado Brkanić. Komentar Zakona o trgovačkim društvima. U: Komentar Zakona o trgovačkim društvima, ur. Vilim Gorenc (ur.), Zagreb: RRiF-plus, 2004.

10. Jelinić, Zvonimir. „Bračna stečevina u kontekstu Zakona o trgovačkim društvima“. U: Zbornik radova sa znanstvenog skupa: Imovinskopravni aspekti razvoda braka-hrvatski, europski i međunarodni kontekst, ur. Branka Rešetar i Mirela Župan. Sveučilište J. J. Strossmayera u Osijeku, 121-136. Osijek: Pravni fakultet, 2011.

11. Rešetar, Branka i Una Josipović. „Sporna pitanja bračne stečevine s osvrtom na bankovne ugovore bračnih drugova“. Zbornik radova Pravnog fakulteta u Splitu 50, br. 1 (2013.), 115-138. 
12. Šimović, Ivan. „Poslovni udjeli u društvu s ograničenom odgovornošću kao predmet bračne stečevine u Republici Hrvatskoj - teorijske dvojbe i izazovi u praksi“. U: Zbornik radova Šesti međunarodni naučni skup Dani porodičnog prava "Imovinskopravni aspekti porodičnih odnosa”, 253-265. Mostar: Pravni fakultet Univerziteta u Mostaru, 2018.

\section{Pravni propisi:}

1. Obiteljski zakon, Narodne novine, br. 103/15., 98/19., 47/20.

2. Obiteljski zakon, Narodne novine, br. 116/03.

3. Obiteljski zakon, Narodne novine, br. 162/98., 116/03.

4. Ovršni zakon, Narodne novine br. 112/12., 25/13., 93/14., 55/16., 73/17., 131/20.

5. Stečajni zakon, Narodne novine, br. 71/15., 104/17.

6. Zakon o braku i porodičnim odnosima, Narodne novine, br. 11/78., 27/78., 45/89., 51/89. - službeni pročišćeni tekst, 59/90., 25/94., 162/98.

7. Zakona o obveznim odnosima, Narodne novine, br. 35/05., 41/08., 125/11., 78/15., 29/18.

8. Zakon o sprječavanju pranja novca i financiranja terorizma, Narodne novine, br. 108/17., $39 / 19$.

9. Zakon o sudskom registru, Narodne novine, br. 1/95., 57/96., 1/98., 30/99., 45/99., 54/05., 40/07., 91/10., 90/11., 148/13., 93/14., 110/15., 40/19.

10. Zakon o trgovačkim društvima, Narodne novine, br. 111/93., 34/99., 121/99., 52/00., 118/03., 107/07., 146/08., 137/09., 152/11. - službeni pročišćeni tekst, 111/12., 125/11., 68/13., 110/15., 40/19.

11. Zakon o vlasništvu i drugim stvarnim pravima, Narodne novine, br. 91/96., 68/98., 137/99., 22/00., 73/00., 114/01., 79/06., 141/06., 146/08., 38/09., 153/09., 90/10., 143/12., 94/17. - službeni pročišćeni tekst, 152/14., 81/15. - službeni pročišćeni tekst.

Sudska praksa:

1. Europski sud za ljudska prava, Odluka o dopuštenosti, Zahtjev br. 33244/02, Nikola Gavella protiv Hrvatske od 11. srpnja 2006., zahtjev broj 33244/02.

2. Ustavni sud Republike Hrvatske U-III-2027/2017 od 11. prosinca 2019.

3. Vrhovni sud Republike Hrvatske Rev 361/92 od 12. ožujka 1992.

4. Vrhovni sud Republike Hrvatske Rev 291/05 od 30. svibnja 2006.

5. Vrhovni sud Republike Hrvatske Rev 393/11 od 5. ožujka 2014.

6. Vrhovni sud Republike Hrvatske Rev 1176/10 od 11. prosinca 2012.

7. Vrhovni sud Republike Hrvatske Rev 1331/08 od 17. prosinca 2009.

8. Vrhovni sud Republike Hrvatske Rev 2128/10 od 18. prosinca 2012.

9. Vrhovni sud Republike Hrvatske Gr1 137/06 od 13. travnja 2006.

10. Vrhovni sud Republike Hrvatske Gr1 38/09-2 od 24. veljače 2009.

11. Vrhovni sud Republike Hrvatske Gr1 526/14 od 8. prosinca 2014.

12. Visoki trgovački sud Republike Hrvatske Pž 80/17 od 18. prosinca 2019.

13. Visoki trgovački sud Republike Hrvatske Pž 2631/15 od 5. siječnja 2016.

14. Visoki trgovački sud Republike Hrvatske Pž 1034/15 od 10. siječnja 2015.

15. Visoki trgovački sud Republike Hrvatske Pž 3111/16 od 1. rujna 2016.

16. Visoki trgovački sud Republike Hrvatske Pž 1496/15 od 16. listopada 2018.

17. Visoki trgovački sud Republike Hrvatske Pž 5432/18 od 16. srpnja 2020.

18. Visoki trgovački sud Republike Hrvatske Pž 2823/19 od 30. svibnja 2019.

19. Visoki trgovački sud Republike Hrvatske Pž 6552/18 od 19. prosinca 2018.

20. Visoki trgovački sud Republike Hrvatske Pž 3073/13 od 19. listopada 2016.

21. Visoki trgovački sud Republike Hrvatske Pž 5014/16 od 29. ožujka 2017.

22. Visoki trgovački sud Republike Hrvatske Pž 855/14 od 13. rujna 2017.

23. Visoki trgovački sud Republike Hrvatske Pž 2575/17 od 8. svibnja 2018.

24. Visoki trgovački sud Republike Hrvatske Pž 2763/18 od 4. svibnja 2020.

25. Visoki trgovački sud Republike Hrvatske Pž 4422/14 od 13. ožujka 2017. 
26. Visoki trgovački sud Republike Hrvatske Pž 3851/18 od 18. lipnja 2018.

27. Visoki trgovački sud Republike Hrvatske Pž 2494/19 od 2. listopada 2020.

28. Visoki trgovački sud Republike Hrvatske Pž 3647/13 od 26. lipnja 2013.

29. Visoki trgovački sud Republike Hrvatske Pž 2597/17 od 28. travnja 2017.

30. Visoki trgovački sud Republike Hrvatske Pž 2911/18 od 18. svibnja 2018.

31. Visoki trgovački sud Republike Hrvatske Pž 4447/20 od 21. listopada 2020.

32. Visoki trgovački sud Republike Hrvatske Pž 1361/19 od 28. veljače 2019.

33. Visoki trgovački sud Republike Hrvatske Pž 1927/18 od 4. travnja 2018.

34. Visoki trgovački sud Republike Hrvatske Pž 7509/17 od 5. siječnja 2018.

35. Visoki trgovački sud Republike Hrvatske Pž 5137/17 od 28. kolovoza 2017.

36. Visoki trgovački sud Republike Hrvatske Pž 4469/2017 od 17. prosinca 2019.

37. Visoki trgovački sud Republike Hrvatske Pž 929/2015 od 6. studenog 2018.

38. Visoki trgovački sud Republike Hrvatske Pž 2155/2018 od 3. travnja 2018.

39. Županijski sud u Varaždinu broj Gž 958/03 od 18. kolovoza 2003.

40. Županijski sud u Varaždinu broj Gž 1064/07 od 13. veljače 2008. 


\section{Tina Jakupak*}

Summary

\section{BUSINESS SHARE(S) AND MARITAL PROPERTY IN PRACTICE OF COMMERCIAL COURTS}

In her daily work, the author deals with litigation and non-litigation cases in which the subject of the dispute is marital property in the business share of a particular company. Through this paper, the author will deal in the first part with the concepts and institutes of marital property and business share, in the second part with legal remedies, lawsuits and proposals for determining a temporary measure to determine marital property with business share, and finally connect it with case law. The paper will try to answer the question of the effects of the previous unilateral disposition of rights whose registered shareholder is (only) one spouse. In this regard, the conflict of family and commercial law rules will be analyzed, with special emphasis on court decisions of commercial courts in the Republic of Croatia, as well as the Supreme Court of the Republic of Croatia. In conclusion, the author gives her view of court proceedings in order to determine the marital property on the business share and the specifics of the property community that the spouses establish as proxies on the business share of the company.

Keywords: business share; marital property; commercial court; case law.

* Tina Jakupak, mag. iur., univ. spec. oec., Judge at Commercial Court in Zagreb; tina.jakupak@ tszg.pravosudje.hr. ORCID: https://orcid.org/0000-0003-3645-2474. 